Article

\title{
Variation in Protein Content and Amino Acids in the Leaves of Grain, Vegetable and Weedy Types of Amaranths
}

\author{
Rita Andini *, Shigeki Yoshida and Ryo Ohsawa \\ Graduate School of Life and Environmental Sciences, University of Tsukuba, \\ 1-1-1 Tennodai Tsukuba-Ibaraki, Japan; E-Mails: syoshida@sakura.cc.tsukuba.ac.jp (S.Y.); \\ osawa.ryo.gt@u.tsukuba.ac.jp (R.O.) \\ * Author to whom correspondence should be addressed; E-Mail: andinijapan@yahoo.com; \\ Tel.: +81-80-4099-1294; +62-813-7050-4702; Fax: +81-29-853-6617.
}

Received: 26 March 2013; in revised form: 20 April 2013 / Accepted: 24 April 2013 /

Published: 3 May 2013

\begin{abstract}
Malnutrition has affected almost 31\% of pre-school children. This paper provides the information of nutritional values (leaf protein, 15 amino acids, biomass and leaf dry matter) of grain, vegetable and weedy types of amaranths ( $n=76$ accessions); particularly those novel materials originated from the highland areas of Sumatra-Takengon. The highest values of leaf protein and total amino acids were found in many weedy species (A. viridis, A. blitum L. and A. dubius). The ranges of leaf protein and total amino acids in

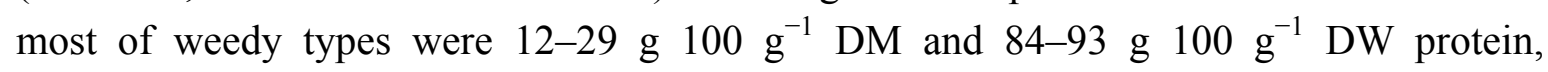
respectively. The leaves of amaranths were found to be a good source for lysine which is the limiting essential amino acids in most of cereal plants. Their values were in the range

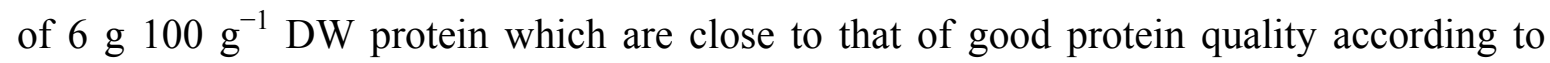
FAO/WHO's standard. The leaves of underutilized weedy species of $A$. dubius, A. blitum, A. viridis and the dual purpose types of $A$. caudatus L., A. cruentus L. deserve to be further exploited as a low cost solution for solving malnutrition problems, especially in Indonesia.
\end{abstract}

Keywords: Amaranthus; genetic diversity; lysine; malnutrition; nutritional values

\section{Introduction}

Malnutrition or the so-called hidden hunger has affected almost $31 \%$ of all children under the age of five years and become a major public health problem in many developing nations [1]. There are two 
variants of malnutrition: micronutrient deficiencies and protein malnutrition [1]; the later one is emphasized in this study. Protein malnutrition is referred to as a condition of poor quality diets, notably with less protein intake and/or low-quality of proteins in terms of amino acid composition in the diets [2]. It has been reported that almost 178 million of pre-school children living in rural and urban areas in Indonesia are malnourished [3]. Most of them come from poor families which are unable to afford animal source protein which is important in children's diets to support their growth [3]. Many stakeholders including non-/governmental agencies have initiated many activities to improve nutritional status via the promotion of biofortified foods' consumption using transgenic approaches and modern plant breeding [4]. Nevertheless, such strategies are less likely to be effective and sustainable for the long term when huge areas, such as Indonesia, need to be covered due to the high operational-, maintenance-and distribution cost [5].

Conventional plant breeding, genetic discoveries and genetic technologies have been proposed as some promising strategies to improve food production and the world's nutrition [4,6]. Many underutilized weedy relatives of lesser-known species bear great potential to be further developed as high quality vegetables for fulfilling the world's demand for high quality foods for human consumption and industry [7,8]. These underutilized vegetables are able to grow well on marginal lands, highly nutritious and protein-rich but still affordable [7,8]. Therefore, the promotion of their consumption can be highlighted as an alternative to alleviate malnutrition in many developing nations in a more sustainable way.

The family of chenopodium, including amaranths, is known as a good source of protein-rich leafy vegetables and an inexpensive source of valuable nutrients, such as dietary fiber, mineral, vitamins, and antioxidant $[9,10]$. Amaranths are generally distinguished as: grain, vegetable and weedy types, depending on their utilization [11]. The seeds of the grain species of $A$. cruentus L., A. caudatus L., $A$. hypochondriacus L. are appreciated as cereals. The first two species are also recognized as the "dual purpose" types as their leaves can also serve as leafy vegetables [11,12]. Meanwhile, the leaves of $A$. tricolor L. have been utilized as vegetables in most tropical countries [13]. A range of protein content of $15 \%-18 \% \mathrm{DM}$ and $12 \%-38 \% \mathrm{DM}$ were reported in the seeds and the leaves of amaranths, respectively [14,15]. The composition of amino acids in amaranths was reported to be close to animal protein with an extra ordinary high content of lysine which is 2 and 3 times higher than that in wheat and maize, respectively [16]. This fact supports the high nutritional quality of amaranths and their recognition as a very promising crop for feeding overpopulated and undernourished areas in developing nations $[9,17]$.

Weedy types of amaranths comprise all species that have not yet been cultivated or may escape out of cultivation [18,19]. A. retroflexus and A. spinosus are classified as "real weeds" and not edible [20]. Contrastingly, up to 17 species which closely resemble the cultivated vegetable amaranths are classified as edible but unfortunately they have not yet been utilized or directed to solve the malnutrition problem $[19,21]$. Their content of protein could reach up to $29 \%-38 \%$ which exceeds the content found in the cultivated A. tricolor L., the protein content of which is in the range of $12 \%-14 \%$ on average $[21,22]$. However, the scant information about the nutritional values (e.g., protein content and amino acids) of those "edible" weedy types of amaranths means they remain untapped.

The availability of genetic variability determines the extent of breeding efforts that a breeder has [23]. The wider the variation, the more possibility there is for crop enhancement. A wealth of 
genetic resources of amaranths in Indonesia has been reported [19]. Some exotic weedy types of amaranths originating from the remote highland areas of Takengon in Sumatra (1200 up to above $2000 \mathrm{~m}$ a.s.l) particularly those uncultivated members of $A$. dubius have been extensively studied and discovered as potential parental lines for high leaf number and protein content improvement [19]. Therefore, information regarding their nutritional values is important for any breeding attempts aiming for the alleviation of malnutrition, particularly in Indonesia. In this work, the variation in protein content, 15 essential amino acids, biomass and leaf dry matter exhibited by the leaves of grain, vegetable and particularly the weedy types of amaranths, including those recently discovered materials originating from Takengon, were assessed. This information will serve further attempts at breeding the vegetable amaranths.

\section{Results and Discussion}

2.1. Variation of Protein Content and Amino Acids in the Leaves of Grain, Vegetable and Weedy Types of Amaranths

The nutritional values (e.g., amino acids, protein and biomass) of the grain, vegetables and weedy types are presented in an integrated study. So far, the majority of the nutritional information in amaranths has emphasized the seeds and very limited studies have dealt with leafy amaranths, particularly the leaves of weedy types [24-26]. Moreover, such information is usually reported separately and not available in one extensive report. Such extensive information is useful for breeders to provide good determinants of high quality vegetables. Moreover, the extent by the nutritional variation exhibited in the three types of amaranths will enable the breeder to determine the limits of breeding efforts in A. tricolor L. as a major vegetable resource [27]. The results reported in these leafy amaranths would complement previous results available in the seeds of amaranths in terms of their nutritional composition.

The nutritional characteristics in amaranths' leaves vary considerably depending on types and species. Table 1 presents the range of the variation of nutritional values of the grain, vegetable and weedy types of amaranths. Further detailed information of the nutritional values (biomass, leaves' dry matter, the values of 15 amino acids, total amino acids and non amino acids) of each accession is presented in the Supplementary Table S1. Most of the investigated nutritional traits showed significant to very highly significant differences among the three types. The total non-protein amino acids were found in relatively small amounts in the three types $(\sim 2 \%)$ and showed no significant differences among the three types (Table 1). 
Table 1. Variation of biomass (BMS, \%), leaves' dry matter (in \%), protein (g $100 \mathrm{~g}^{-1} \mathrm{DW}$ ) and amino acids of amaranths (g $100 \mathrm{~g}^{-1} \mathrm{DW}$ protein) of the grain, vegetable and weedy types of amaranths.

\begin{tabular}{|c|c|c|c|c|c|c|c|c|c|c|c|c|c|c|c|c|}
\hline \multirow[b]{2}{*}{ Nr. } & \multirow[b]{2}{*}{ Traits } & \multirow[b]{2}{*}{ Unit } & \multicolumn{4}{|c|}{ GRAIN $(N=12)$} & \multicolumn{4}{|c|}{ VEGETABLE $(N=37)$} & \multicolumn{4}{|c|}{ WEEDY $(N=27)$} & \multirow[b]{2}{*}{$F$-value } & \multirow[b]{2}{*}{$P>F$} \\
\hline & & & Min. & Mean & Max. & S.D. & Min. & Mean & Max. & S.D. & Min. & Mean & Max. & S.D. & & \\
\hline 1 & BMS & $(\%)$ & 13.20 & 15.55 & 17.81 & 1.68 & 7.57 & 14.83 & 27.57 & 4.64 & 5.85 & 17.94 & 25.42 & 4.33 & 4.13 & $*$ \\
\hline 2 & Leaves’ DM & $(\%)$ & 12.64 & 19.69 & 24.37 & 3.10 & 10.97 & 19.16 & 29.22 & 5.31 & 11.55 & 23.23 & 37.70 & 6.34 & 4.37 & $* *$ \\
\hline 3 & Protein & (g $\left.100 \mathrm{~g}^{-1} \mathrm{DW}\right)$ & 10.78 & 15.71 & 20.31 & 2.82 & 11.59 & 16.22 & 28.03 & 3.56 & 11.84 & 19.40 & 29.06 & 4.71 & 6.29 & $* *$ \\
\hline 4 & Leu & (g $100 \mathrm{~g}^{-1}$ DW Protein) & 6.71 & 7.46 & 8.19 & 0.53 & 6.82 & 7.81 & 8.48 & 0.37 & 5.44 & 7.87 & 8.40 & 0.55 & 3.34 & * \\
\hline 5 & Ala & (g $100 \mathrm{~g}^{-1}$ DW Protein) & 5.59 & 5.97 & 6.55 & 0.34 & 5.21 & 6.07 & 1.72 & 0.28 & 5.37 & 6.59 & 7.69 & 0.60 & 14.42 & $* * *$ \\
\hline 6 & Lys & (g $100 \mathrm{~g}^{-1}$ DW Protein) & 5.50 & 5.92 & 6.42 & 0.30 & 5.18 & 6.05 & 6.63 & 0.36 & 5.63 & 6.13 & 6.54 & 0.25 & 1.77 & n.s. \\
\hline 7 & Gly & (g $100 \mathrm{~g}^{-1}$ DW Protein) & 5.59 & 6.15 & 6.96 & 0.38 & 5.42 & 5.88 & 6.34 & 0.22 & 5.26 & 5.85 & 6.70 & 0.36 & 4.51 & $* *$ \\
\hline 8 & Ser & (g $100 \mathrm{~g}^{-1}$ DW Protein) & 4.55 & 5.40 & 5.69 & 0.30 & 2.63 & 5.33 & 6.08 & 0.52 & 5.02 & 5.54 & 6.11 & 0.32 & 1.89 & n.s. \\
\hline 9 & Arg & (g $100 \mathrm{~g}^{-1}$ DW Protein) & 4.27 & 4.73 & 5.27 & 0.35 & 4.50 & 5.15 & 6.01 & 0.27 & 4.66 & 5.21 & 5.80 & 0.26 & 13.35 & $* * *$ \\
\hline 10 & Thr & (g $100 \mathrm{~g}^{-1}$ DW Protein) & 4.41 & 4.86 & 5.28 & 0.28 & 4.67 & 5.00 & 5.22 & 0.13 & 4.68 & 5.03 & 5.39 & 0.19 & 3.88 & $*$ \\
\hline 11 & Phe & (g $100 \mathrm{~g}^{-1}$ DW Protein) & 4.12 & 4.49 & 4.92 & 0.28 & 4.04 & 4.63 & 5.12 & 0.25 & 4.38 & 4.83 & 5.36 & 0.20 & 9.93 & $* * *$ \\
\hline 12 & Pro & (g $100 \mathrm{~g}^{-1}$ DW Protein) & 4.08 & 4.53 & 5.09 & 0.28 & 3.89 & 4.72 & 5.67 & 0.36 & 3.99 & 4.68 & 5.53 & 0.35 & 1.31 & n.s. \\
\hline 13 & Val & (g $100 \mathrm{~g}^{-1}$ DW Protein) & 3.67 & 4.43 & 5.18 & 0.44 & 4.03 & 4.76 & 5.25 & 0.32 & 3.25 & 4.45 & 5.32 & 0.65 & 4.01 & $* *$ \\
\hline 14 & Ile & (g $100 \mathrm{~g}^{-1}$ DW Protein) & 3.18 & 3.78 & 4.33 & 0.37 & 3.48 & 4.04 & 4.76 & 0.32 & 2.67 & 3.86 & 6.25 & 0.75 & 1.60 & n.s. \\
\hline 15 & Tyr & (g $100 \mathrm{~g}^{-1}$ DW Protein) & 2.74 & 3.65 & 4.19 & 0.40 & 2.87 & 3.62 & 4.15 & 0.32 & 3.30 & 3.73 & 4.46 & 0.24 & 1.10 & n.s. \\
\hline 16 & His & (g $100 \mathrm{~g}^{-1}$ DW Protein) & 1.87 & 1.99 & 2.10 & 0.07 & 1.41 & 1.78 & 2.10 & 0.17 & 1.68 & 1.84 & 2.22 & 0.11 & 9.65 & $* * *$ \\
\hline 17 & Cys & (g $100 \mathrm{~g}^{-1}$ DW Protein) & 0.45 & 0.53 & 0.62 & 0.05 & 0.00 & 0.42 & 0.83 & 0.22 & 0.00 & 0.50 & 1.06 & 0.22 & 1.92 & n.s. \\
\hline 18 & Met & (g $100 \mathrm{~g}^{-1}$ DW Protein) & 0.00 & 0.27 & 0.75 & 0.25 & 0.00 & 0.32 & 1.22 & 0.32 & 0.00 & 0.52 & 2.39 & 0.48 & 2.90 & n.s. \\
\hline 19 & Total AA & (g $100 \mathrm{~g}^{-1}$ DW Protein) & 80.35 & 85.37 & 91.24 & 3.48 & 79.77 & 88.60 & 91.39 & 2.23 & 84.40 & 90.42 & 92.96 & 1.68 & 20.15 & $* * *$ \\
\hline 20 & Total NPAA & (g $100 \mathrm{~g}^{-1}$ DW Protein) & 1.05 & 2.04 & 3.10 & 0.63 & 0.93 & 2.03 & 3.32 & 0.65 & 0.89 & 1.78 & 3.63 & 0.76 & 1.19 & n.s. \\
\hline
\end{tabular}

Min., minimum; Max. maximum; S.D., Standard Deviation; N, number of samples; AA, Amino Acids; NPAA, Non Protein Amino Acids. n.s., not significant; * and **,

*** represent significance at $P<0.05$ and $P<0.01, P<0.001$, respectively. 
The weedy amaranths showed wider variation and higher mean values in most of the nutritional values investigated if comparing with those values observed in the leaves of the grain and the vegetable types (Table 1). The weedy types showed the highest protein content on average (19 $\mathrm{g}$ $100 \mathrm{~g}^{-1}$ DW of protein) (Table 1) with the highest one observed in A. viridis (USDA 30/PI $540445 /$ IDN/Java). The second highest value of protein was observed in $A$. dubius (IDN 01/Mongal, IDN 02/Daling, IDN 03/Daling) and in A. blitum L. (IDN 18/Medan, IDN 19/Mandua) (Table S1). The content of protein in the leaves of those three weedy species was found to be 2.0, up to 2.5 higher than that found in A. tricolor L. which is applied as a reference value in this study. According to Shukla $e t$

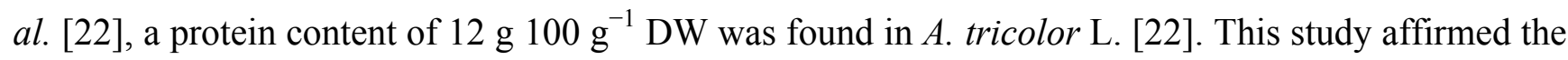
superiority of the nutritional values found in the leaves of weedy types. Furthermore, the total amino

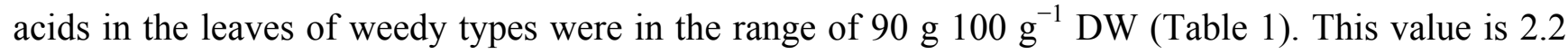
higher than that reportedly found in the seeds of amaranths [26]. These results support the potential utilization of weedy species to be incorporated as an alternative high quality protein food source for many developing nations and served as potential crops to be developed as new food and beverage products, such as in the case of South Africa [27,28]. The higher variation observed in most of wild or weedy plants are in accordance with Pickersgill [29]. In addition, Guil et al. [30] acknowledged the superiority of wild edible plants in terms of their nutrients. Due to these studies, many researchers have suggested further genetic discoveries, including the utilization and incorporation of many underutilized crops to address food and nutrition-security [30,31]. Therefore, their nutritional assessment is a prerequisite for further utilization and nutritional security.

The vegetable types exhibited the second highest nutritional values on average. The vegetable amaranths had slightly higher protein content and a similar value of leaves' dry matter on average than the leaves of grains (Table 1). However, Fomsgaard et al. [32] reported a higher content of protein in the leaves of vegetable amaranth than the leaves of grain species. Moreover, USDA 26/PI 477918/N.A showed the highest leaves' dry matter value among the three types (Table S1). The high value of leaves' dry matter is a distinct characteristic, which is important to the vegetables utilization as a fiber source in human diets. Furthermore, the Recommended Dietary Allowances (RDA) value of protein is $0.66 \mathrm{~g} / \mathrm{kg}$ per day [33]. RDA is the average daily dietary intake level sufficient to meet the nutrient requirements of healthy individuals. Based on this result, an average consumption of $100 \mathrm{~g}$ per day of (fresh) vegetable amaranths is necessary to meet the protein requirement for the human body [20].

The leaves of the dual purpose amaranths (A. cruentus L. and A. caudatus L.) showed almost comparable values in protein content and in their composition of amino acids with the leaves of vegetable amaranths (Table 1 and Supplementary Table S1). This condition implies that, despite the "no intense" human selection by the leaves of the dual purpose types, nevertheless, they can be selected as parental lines for yield performance from the "picking types" of vegetable amaranths in Indonesia. There are two types of vegetable amaranths that are known In Indonesia, distinguished by the way they are harvested: (1) the uprooting type; (2) the picking type. The common type is the uprooting one [34]. These dual types may be incorporated in improving the morphological performance of the picking types of vegetable amaranths due to their unique characteristics such as taller plants, bigger leaf sizes but high protein content. Another potential application for the dual type is as fodder crop due to their relatively high protein content [35]. 
Lysine, the major target in this study was found to be in the range of 5 to $7 \mathrm{~g} 100 \mathrm{~g}^{-1} \mathrm{DW}$ protein and was not significantly different among the three types (Table 1). No significant differences among the three types of amaranths in terms of their lysine means that any types of amaranths are highly

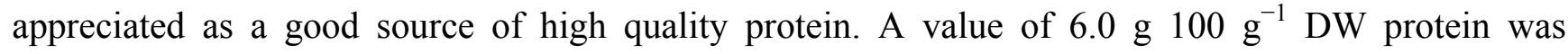
observed in most of the vegetable and weedy types, such as A. tricolor L., A. dubius and also in the leaves of grain species such as $A$. cruentus (USDA 07/PI 482051/ZWE, USDA 13/PI 604666/USDA), A. hypochondriacus (USDA 21/PI 604577/MEX, USDA 22/PI 604796/N.A) and A. hybridus (IDN

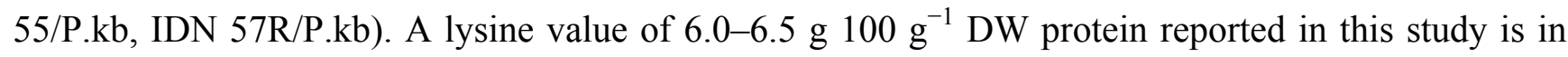
line with the previous one reported by Grubben [20]. A good value of lysine is $7 \mathrm{~g}^{100 \mathrm{~g}^{-1} \mathrm{DW}}$ according to the protein reference pattern defined by FAO/WHO [33] which is usually exhibited in egg or milk proteins. Both are usually applied as a reference standard for high biological value in protein [36]. The daily requirement of lysine for infants and adults, including children of school age is

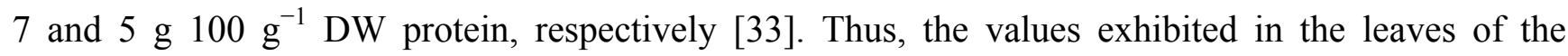
three types of amaranths are close to the ideal value and this study confirms that the highly appreciable lysine content in the leaves of amaranths could support its recommendation by food nutritionists [36,37].

There are several weak points that are acknowledged in amaranths. First, leucine, valine and threonine are reported to be the limiting essential amino acids in the seeds of amaranths [35]. In our study, cysteine and methionine were found to be present in very small amounts. The relatively low values in cysteine and methionine in this study might be explained by two possible causes: they might have been denaturized during analysis or their values are indeed found to be very limited in amaranths,

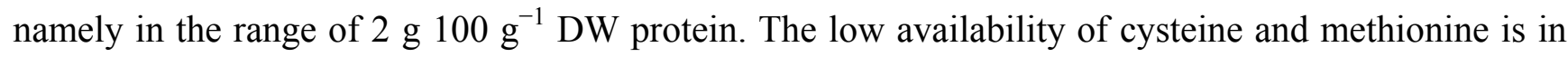
accordance with the previous studies [20,38]. To compensate this limitation in amaranths, a highly diverse food intake in the dishes via additional consumption of plant-/non plant-origin proteins such as milk, animal proteins and lentils or pulses are highly recommended [26,37]. Secondly, the relatively high content of oxalate, which could exceed $1000 \mathrm{mg}$ per $100 \mathrm{~g}$ of plant weight, is counted as one of the major challenges in the exploitation of weedy types [30]. The oxalate content, an anti nutritive element, should be perceived with caution in the consumption of amaranths. However, a consumption of 300-500 g fresh leaves is determined as the limit of the toxicity level $[11,20]$. Discarding the cooking water might reduce the content of oxalic acid and support the safe consumption of amaranths [20].

Malnutrition, such as anemia, vitamin A and protein deficiencies have affected one hundred million, nine million and twelve million people in the Indonesian population, respectively. These huge numbers of malnourished people are mainly children of school age, mostly from rural and isolated parts of Indonesia [39]. Despite its inferiority as a so-called "underutilized crop", the high nutritional quality of vegetable amaranths has been recognized [40]. This paper supports the utilization and promotion of amaranths as potential plants to combat the malnutrition problem in densely populated and huge areas such as in Indonesia at low cost [11]. 


\section{Experimental Section}

\subsection{Plant Materials}

The leaves of 76 amaranths' accessions belong to 10 species utilized as grain, vegetable and weedy types were selected for this study (Supplement Table S1). Seeds of the worldwide collection (27 accessions) were provided by the United States Department of Agriculture-Agriculture Research Service (USDA-ARS), North Central Regional Plant Introduction Station (NCRPIS) in Ames (Iowa, USA). The species identification for the worldwide collection was performed by USDA personnel and available online [41]. The Indonesian materials (49 accessions) were collected from Sumatra and Java islands of Indonesia (Figure 1). Seeds were classified on the basis of their utilization (as weedy or vegetable types), as indicated by local farmers and according to amaranth's descriptors [42]. The vegetable seeds were provided freely from farmers in Sumatra and Java. The weedy types were collected from various sites (villages, urban areas, disturbed habitats, open or abandoned places, river banks, communal forests at the mountainous areas) in 2008 and 2010.

Figure 1. Map of the sample collection regions (blue dots) for Indonesian amaranths.

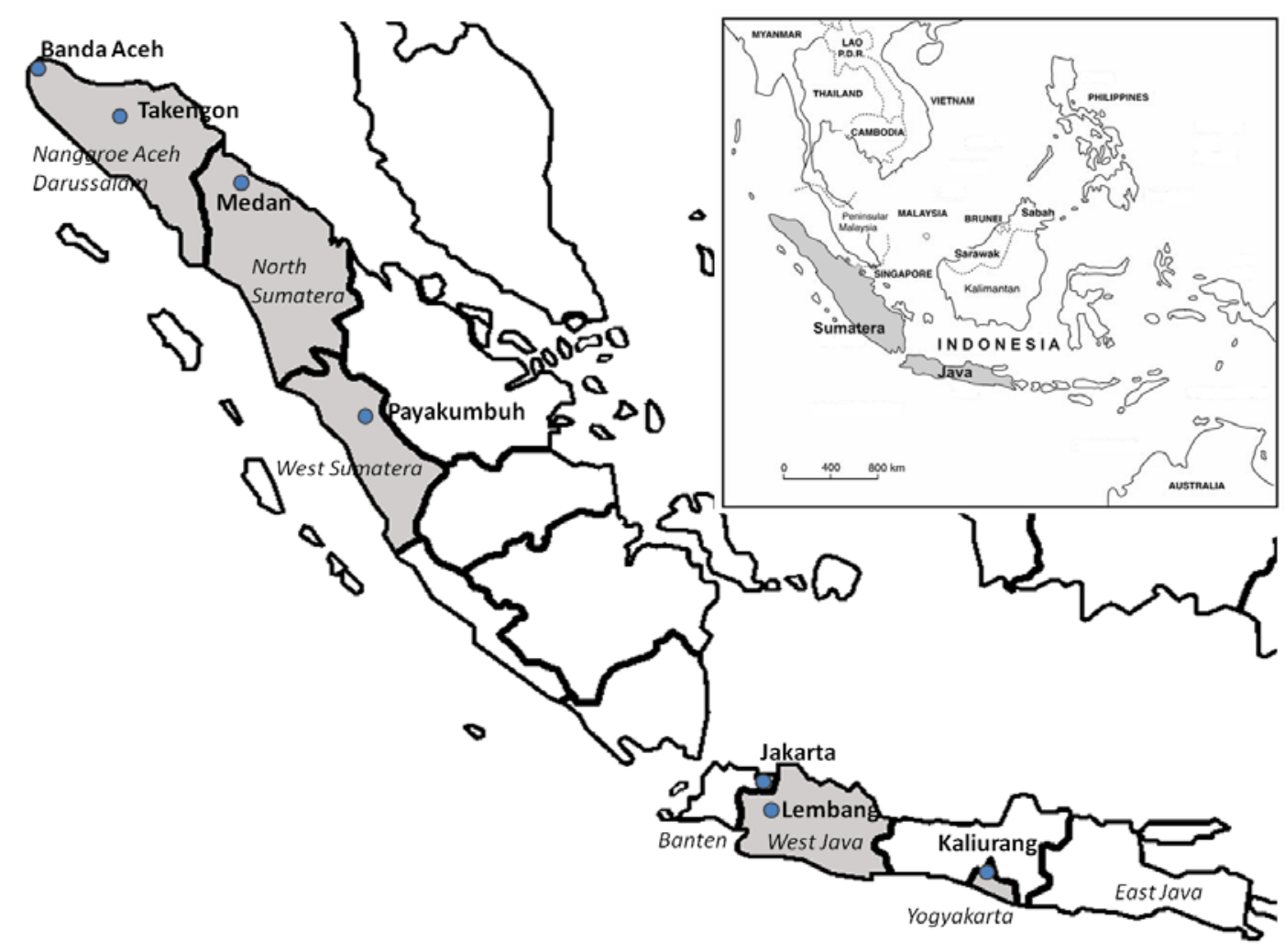

\subsection{Experimental Site}

The experiment was conducted in summer 2010 in vinyl houses on the experimental field at the Agriculture and Forestry Centre, University of Tsukuba, Japan, which is situated at $28 \mathrm{~m}$ above sea level at $36^{\circ} 07^{\prime} 01.71^{\prime \prime}$ latitude and $140^{\circ} 05^{\prime} 40.24^{\prime \prime}$ longitude. Seeds were germinated in plastic trays $(6 \times 6$ holes; diameter, $4 \mathrm{~cm}$; depth, $4.7 \mathrm{~cm})$ containing growing medium without fertilizer ("Metromix 350" from Sungro). Three weeks after sowing, amaranths' seedlings (3-4 plants) were transplanted 
and raised in soil pots with $18 \mathrm{~cm}$ of diameter and $16.5 \mathrm{~cm}$ of height containing ready soil "Sumirin". Pots were arranged according to a completely randomized design.

\subsection{Sample Preparation}

Between 2-3 months after sowing date, 10-25 g fresh leaves were cut from each plant per accessions (Figure 2). Leaves were ground in liquid nitrogen and then freeze dried (EYELA, Tokyo Rikakikai Co Ltd., FD-1) for 2-3 days. The freeze-dried samples were filtered with metal sieves (100-125 mesh size) and the fine powder was employed for protein analysis and amino acids' determination. Analysis was performed in duplicate for each accession number.

Figure 2. The leaves of $A$. cruentus L. as the representative of grain amaranths (A); A. tricolor $\mathrm{L}$. the most prominent vegetable (B); and $A$. dubius as the representative of edible weedy amaranths (C).
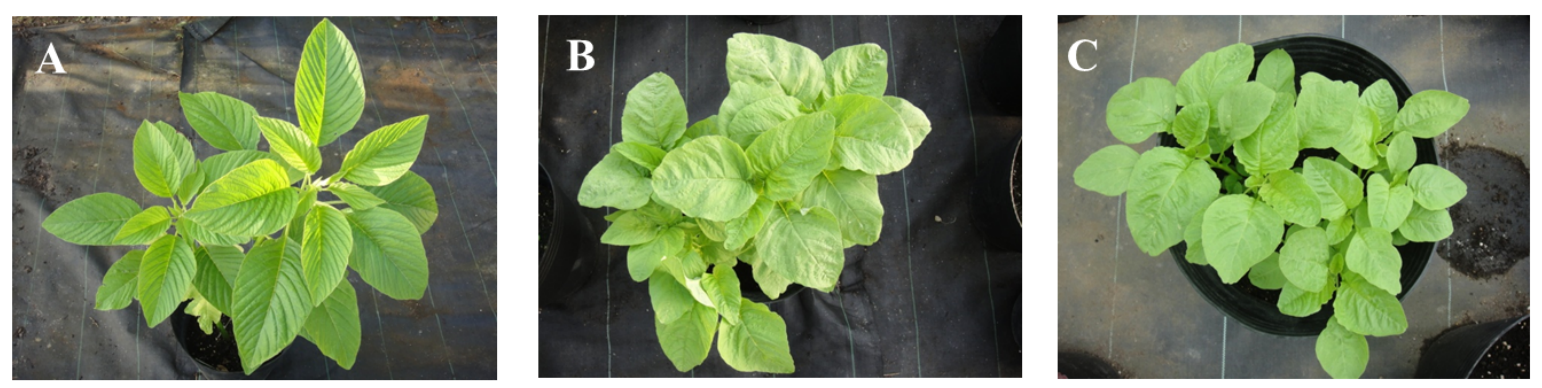

\subsection{Biomass (BMS)}

At flowering time, the whole plant, except for the roots and five leaves, was cut and put in an A4- paper bag (which will henceforth be referred to as "bag"). The sample (bag containing one plant) was freshly weighted on a scale (CPA 4202S, Sartorius Weighing Technology GmbH, Göttingen, Germany) and noted as total fresh weight $\left(\mathrm{FW}_{\text {sample }}\right)$. Prior to that, each empty bag was freshly weighed and noted as $\mathrm{FW}_{\text {bag. }}$. Four paper bags were prepared for each accessions and dried at $65{ }^{\circ} \mathrm{C}$ in an oven (MOV-2 1 2(U), Sanyo, Made in UK). The weight was checked weekly. The final dry weight of samples ( $\left.\mathrm{DW}_{\text {sample }}\right)$ was recorded after their weight was constant (approximately after 2 weeks). Along with the samples, three paper bags with similar sizes were dried in the same oven. After drying, the dried weight of paper was averaged and noted as $\mathrm{DW}_{\text {bag. }}$. All calculation was determined in grams (g). Biomass (BMS) was calculated following this formula:

$$
\operatorname{BMS}(\%)=\left[\left(\mathrm{DW}_{\text {sample }}-\mathrm{DW}_{\text {bag }}\right) /\left(\mathrm{FW}_{\text {sample }}-\mathrm{FW}_{\text {bag }}\right)\right] \times 100
$$

BMS-values presented were means of measurements on four plants for each accession and determined in $\% \mathrm{DM}$.

\subsection{Leaves’ Dry Matter (DM)}

At flowering time, five leaves were cut from each plant per pot and put in a small paper bag (dimension: $18 \times 7 \mathrm{~cm}$ ). The applied drying procedure and the end calculation of the leaves' DM were 
similar with the ones previously described in "Biomass". All calculation was determined in grams (g). Leaves' Dry Matter (DM) values presented were means of duplicates per accession number and determined in \% DM.

\subsection{Protein Analysis}

One milligram of powdered material was prepared in duplicate for protein analysis. Crude protein content was determined by the Kjeldahl method; protein content was determined as percentage of dry weight by multiplying the nitrogen content $(\mathrm{N})$ by the conversion factor of $6.25(\mathrm{~N} \times 6.25)$ [43]. The protein content was calculated as $\mathrm{g} 100 \mathrm{~g}^{-1} \mathrm{DW}$.

\subsection{Amino Acids Determination}

\subsubsection{Sample Preparation}

One milligram powdered samples with $1 \mathrm{~mL} 6 \mathrm{~N} \mathrm{HCl}$ were put in cylinder glass tube and oxidized under (cold-) vacuum condition. The vacuum-sealed glass tube was hydrolyzed for $24 \mathrm{~h}$ at $110{ }^{\circ} \mathrm{C}$ (PIERCE Reacti Therm 18870). The vacuum-dried hydrolysate was then added with $5 \mathrm{~mL}$ distilled water and then centrifuged at $3000 \mathrm{rpm}$ (LC06 SP Tommy-Seiko Co. Ltd, Tokyo, Japan) for $10 \mathrm{~min}$. The supernatant was withdrawn with a pipette, filtered through a $0.45-\mu \mathrm{m}$ filter and placed into an Erlenmeyer flask $\left(\mathrm{V}_{\max }=20 \mathrm{~mL}\right)$. Five milliliters distilled water was added in the flask. Rotary Vapory Evapometer (RE 300 LC06 SP Tomy-Seiko Co. Ltd, Tokyo, Japan) was applied to remove $\mathrm{HCl}$ in the solution. After the solution had dried up, $5 \mathrm{~mL}$ sodium acetate buffer was added to dissolve the solution. The solution was then filtered through a $0.22-\mu \mathrm{m}$ filter. About $300 \mu \mathrm{L}$ of the filtrate was ready to be delivered to the analytical center of the University of Tsukuba.

\subsubsection{Amino Acid Determination}

The sample $(50 \mathrm{nmol} / \mathrm{mL})$ was applied on an automatic amino acid analyzer JEOL (JLC 500/V). The amino acids were calculated as $\mathrm{g}$ in $100 \mathrm{~g}^{-1} \mathrm{DW}$ protein. The sum of the 17 amino acids is defined as the Total Amino Acids (abbreviated as TAA). They are: Glx, Glutamic Acid or Glutamine; Asx, Aspartic Acid or Asparagine; Leu, Leucine; Ala, Alanine; Lys, Lysine; Glys, Glysine; Ser, Serine; Arg, Arginine; Thr, Threonine; Phe, Phenylalanine; Pro, Proline; Val, Valine; Ile, Isoleucyne; Tyr, Tyrosine; His, Histidine; Cys, Cysteine; Met, Methionine (Supplementary Table S1). Meanwhile, the sum of P-Serine, Ornithine, Citrulline is defined as the Total Non Protein Amino Acids (abbreviated as TNPAA) (Table S1).

\subsection{Statistical Analysis}

Analysis of variance (ANOVA) was applied to each of the accessions and differences among traits $(P<0.05)$ were determined by t-test means comparison by using JMP version 7.0 (SAS Institute, Cary, NC, USA). 


\section{Conclusions}

It is concluded from the present study that the three types of amaranths (grain, vegetable and weedy types) show a wide array of highly nutritional characteristics, particularly the edible weedy species

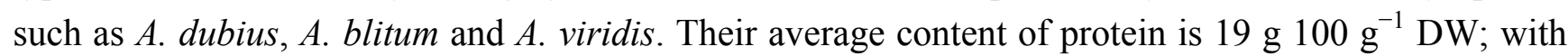

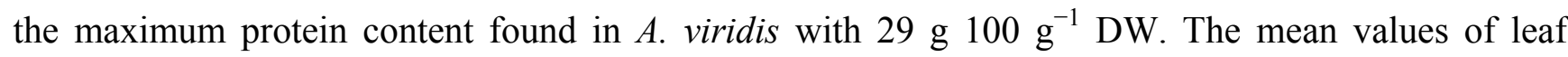

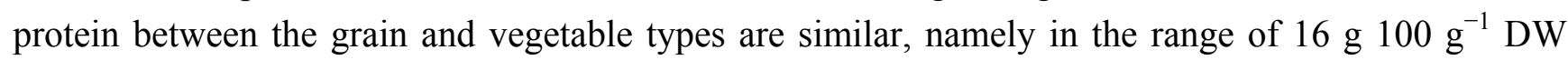
protein. Furthermore, the dual type species (A. caudatus L. and A. cruentus L.) have protein content in

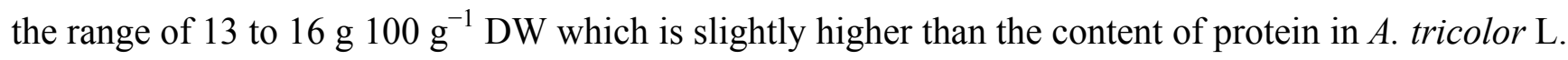
which is applied as reference in this study. Thus, they can be prospected as parental lines in the morphology and nutritional quality improvement of the picking types of vegetable amaranths. Moreover, the values of lysine in the leaves of the three types of amaranths is close to an ideal protein

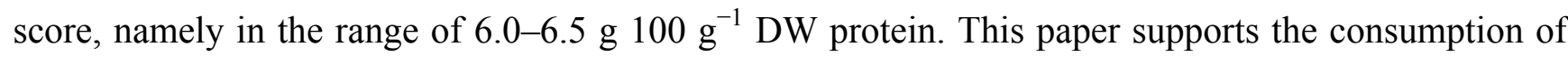
leafy amaranths as an alternative solution to alleviate malnutrition problems in Indonesia at low cost.

\section{Conflict of Interest}

The authors declare no conflict of interest.

\section{Acknowledgments}

We kindly acknowledge David Brenner for the contribution of worldwide seeds of amaranths. Our sincere gratitude is extended to all farmers from Sumatra and Java who provided the seeds freely for this experiment. This study was financed by the Japanese Ministry of Education, Culture, Sports, Science and Technology (MEXT scholarship).

\section{References}

1. Müller, O.; Krawinkel, M. Malnutrition and health in developing countries. Can. Med. Assoc. J. 2005, 173, 279-286.

2. Chakraborty, S.; Chakraborty, N.; Agrawal, L.; Ghosh, S.; Narula, K.; Shekhar, S.; Naik, P.S.; Pande, P.C.; Chakrborti, S.K.; Datta, A. Next-generation protein-rich potato expressing the seed protein gene AmA1 is a result of proteome rebalancing in transgenic tuber. Proc. Natl. Acad. Sci. 2010, $1-6$.

3. Sari, M.; de Pee, S.; Bloem, M.W.; Sun, K.; Thorne-Lyman, A.L.; Moench-Pfanner, R.; Akhter, N.; Kraemer, K.; Semba, R.D. Higher household expenditure on animal-source and nongrain foods lowers the risk of stunting among children 0-59 months old in Indonesia: Implications of rising food prices. J. Nutr. 2010, 140, 195S-200S.

4. Welch, R.M.; Graham, R.D. Breeding for micronutrients in staple food crops from a human nutrition perspective. J. Exp. Bot. 2004, 55, 353-364.

5. Persson, V. Vitamin A Intake, Status and Improvement Using the Dietary Approach. Ph.D Thesis, Faculty of Medicine Uppsala University, Uppsala, Sweden, 2001.

6. Huang, J.; Pray, C.; Rozelle, S. Enhancing the crops to feed the poor. Nature 2002, 418, 678-684. 
7. Gupta, S.; Jyothi Lakshmi, A.; Manjunath, M.N.; Prakash, J. Analysis of nutrient and antinutrient content of underutilized green leafy vegetables. LWT Food Sci. Technol. 2005, 38, 339-345.

8. Barba de la Rosa, A.P.; Fomsgaard, I.S.; Laursen, B.; Mortensen, A.G.; Olvera-Martínez, L.; Silva-Sánchez, C.; Mendoza-Herrera, A.; González-Castañeda, J.; De León-Rodríguez, A. Amaranth (Amaranthus hypochondriacus) as an alternative crop for sustainable food production: phenolic acids and flavonoids with potential impact on its nutraceutical quality. J. Cereal Sci. 2009, 49, 117-121.

9. Gupta, K.; Wagle, D.S. Nutritional and antinutritional factors of green leafy vegetables. J. Agric. Food Chem. 1988, 36, 472-474.

10. Caselato Sousa, V.M.; Amaya-Farfán, J. State of knowledge on amaranth grain: a comprehensive review. J. Food Sci. 2012, 77, R93-R104.

11. Brenner, D.M.; Baltensperger, D.D.; Kulakow, P.A.; Lehmann, J.W.; Myers, R.L.; Slabbert, M.M.; Sleugh, B.B. Genetic resources and breeding of Amaranthus. Plant Breed. Rev. 2000, 19, 227-285.

12. Coons, M.P. Relationships of Amaranthus caudatus. Econ. Bot. 1982, 36, 129-146.

13. Grubben, G.J.H. Amaranthus L. In Plant Resources of South-East Asia No 8 Vegetables; Siemonsma, J.S., Piluek, K., Eds.; Prosea Foundation: Bogor, Indonesia, 1994; pp. 82-86.

14. Barba de la Rosa, A.P.; Gueguen, J.; Paredes-López, O.; Viroben, G. Fractionation procedure, electrophoretic characterization, and amino acid composition of amaranth seed proteins. J. Agric. Food Chem. 1992, 40, 931-936.

15. Barba de la Rosa, A.P.; Silva-Sánchez, C.; González de Mejia, E. ACS symposium series: Amaranth: An ancient crop for modern technology. In Hispanic Foods; Tunick, M., Ed.; American Chemical Society: Washington, DC, USA, 2006; pp. 103-116.

16. Zheleznov, A.V.; Solonenko, L.P.; Zheleznova, N.B. Seed proteins of the wild and the cultivated Amaranthus species. Euphytica 1997, 97, 177-182.

17. Maughan, P.J.; Sisneros, N.; Luo, M.; Kudrna, D.; Ammiraju, J.S.S.; Wing, R.A. Construction of an Amaranthus hypochondriacus bacterial artificial chromosome library and genomic sequencing of herbicide target genes. Plant Genome 2008, 1, S85-S94.

18. Pal, M. Evolution and improvement of cultivated amaranths. III. Amaranthus spinosus-dubius complex. Genetica 1972, 43, 106-118.

19. Andini, R.; Yoshida, S.; Yoshida, Y.; Ohsawa, R.O. Amaranthus genetic resources in Indonesia: Morphological and protein content assessment in comparison with worldwide amaranths. Gen. Resour. Crop Evol. 2013, doi:10.1007/s10722-013-9979-y. Available online: http://link.springer. com/content/pdf/10.1007\%2Fs10722-013-9979-y.pdf (accessed on 2 May 2013).

20. Grubben, G.J.H. The Cultivation of Amaranth as a Tropical Leaf Vegetable with Special Reference to South Dahomey; Department of Agricultural Research of the Royal Tropical Institute: Amsterdam, The Netherland, 1976; pp. 1-207.

21. Grubben, G.J.H. Amaranthus dubius Mart. Ex. Thell [Internet] Record from Protabase. In Plant Resources of Tropical Africa (PROTA); Grubben, G.J.H., Denton, O.A., Eds.; Plant Resources of Tropical Africa/Ressources végétales de l'Afrique tropicale (PROTA): Wageningen, The Netherlands, 2004. Available online: http://www.prota.org/index.php?option=com_content $\&$ view=frontpage\&Itemid=128\&lang=en (accessed on 14 March 2013). 
22. Shukla, S.; Bhargava, A.; Chatterjee, A.; Pandey, A.C.; Mishra, B.K. Diversity in phenotypic and nutritional traits in vegetable amaranth (Amaranthus tricolor), a nutritionally underutilized crop. $J$. Sci. Food Agric. 2010, 90, 139-144.

23. Pfeiffer, W.; McClafferty, B. HarvestPlus: Breeding crops for better nutrition. Crop Sci. 2007, 47, S88-S105.

24. Becker, R.; Wheeler, E.L.; Lorenz, K.; Stafford, A.E.; Grosjean, O.K.; Betschart, A.A.; Saunders, R.M. A compositional study of amaranth grain. J. Food Sci. 1981, 46, 1175-1180.

25. Gorinstein, S.; Moshe, R. Evaluation of four Amaranthus species through protein electrophoretic patterns and their amino acid composition. J. Agric. Food Chem. 1991, 39, 851-854.

26. Gorinstein, S.; Delgado-Licon, E.; Pawelzik, E.; Permady, H.H.; Weisz, M.; Trakhtenberg, S. Characterization of soluble amaranth and soybean proteins based on fluorescence, hydrophobicity, electrophoresis, amino acid analysis, circular dichroism, and differential scanning calorimetry measurements. J. Agric. Food Chem. 2001, 49, 5595-5601.

27. Shukla, S.; Bhargava, A.; Chatterjee, A.; Srivastava, A.; Singh, S.P. Estimates of genetic variability in vegetable amaranth (A. tricolor) over different cuttings. Hort. Sci. 2005, 32, 60-67.

28. Van Wyk, B.E. The potential of South African plants in the development of new food and beverage products. South Afr. J. Bot. 2011, 77, 857-868.

29. Pickersgill, B. Biosystematics of crop-weed complexes. Kulturpflanze 1981, 19, S377-S388.

30. Guil, J.L.; Rodriguez-Garcia, I.; Torija, E. Nutritional and toxic factors in selected wild edible plants. Plant Foods Hum. Nutr. 1997, 51, 99-107.

31. Introduction to the International Treaty on Plant Genetic Resources for Food and Agriculture, 1st ed.; Food and Agriculture Organization: Rome, Italy, 2011; pp. 1-155.

32. Fomsgaard, I.S.; Añon, M.C.; Barba de la Rosa, A.P.; Christophersen, C.; Dusek, K.; Délano-Frier, J.; Espinoza Pérez, J.; Fonseca, A.; Janovská, D.; Kudsk, P.; et al. Adding value to holy grain: Providing the key tools for the exploitation of amaranth-the protein rich grain of the Aztecs, Results from a joint European-Latin American Research Project. In Amaranth: Future Food; Department of Integrated Pest Management, Faculty of Agricultural Sciences, Aarhus University: Aarhus, Denmark, 2009; pp. 1-77.

33. Protein and Amino acid Requirements in Human Nutrition; Report of a Joint WHO/FAO/UNU Expert Consultation (WHO Technical Report Series; No. 935); World Health Organization: Geneva, Switzerland, 2007; pp. 1-284.

34. Hadisoeganda, R.W.W. Amaranth: Livelihood Support for Farmers in Indonesia (in Indonesian); No 8; A Monograph Produced by the Indonesian Vegetable Research Institute: Lembang, Indonesia, 1996.

35. Pedersen, B.; Kalinowski, L.S.; Eggum, B.O. The nutritive value of amaranth grain (Amaranthus caudatus). Plant Foods Hum. Nutr. 1987, 36, 309-324.

36. Coultate, T.P. Food, the Chemistry of Its Composition, 4th ed.; RSC publication: Cambridge, Country, 2002; pp. 138.

37. National Academy of Science. Lost Crops of Africa: Grains; The National Academies Press: Washington, DC, USA, 1996; Volume I, pp. 1-408.

38. Bressani, R.; García-Vela, L.A. Protein fractions in amaranth grain and their chemical characterization. J. Agric. Food Chem. 1990, 38, 1205-1209. 
39. Wargiono, J.; Richana, N.; Hidajat, A. Contribution of cassava leaves used as a vegetable to improve human nutrition in Indonesia, 2002. Available online: http://webapp.ciat.cgiar.org/asia cassava/workshop_pdf/Paper16_J_Wargiono_N_Richana_and_A_Hidajat_Contribution_of_c.pdf (accessed on 14 March 2013).

40. National Academy of Sciences. Lost Crops of Africa: Vegetables; The National Academies Press: Washington, DC, USA, 2006; Volume II, pp. 1-379.

41. United States Department of Agriculture-Agriculture Research Service (USDA-ARS). National Genetic Resources Program Germplasm Resources Information Network (GRIN) [Online Database]. National Germplasm Resources Laboratory: Beltsville, Maryland, 2011. Available online: http://www.ars-grin.gov/npgs/ (accessed on 14 March 2013).

42. Brenner, D.M. Amaranth Descriptor. Descriptor Site(s):NC7; USDA: Iowa City, IA, USA, 2002; pp. 1-13. Available online: http://www.ars-grin.gov/npgs/descriptors/amaranth (accessed on 14 March 2013).

43. AOAC Kjeldahl method for nitrate containing samples-Official final action. In Official Methods of Analysis of the Association of Official Analytical Chemists; Association of Official Analytical Chemists: Washington, DC, USA, 1980; p. 15.

(C) 2013 by the authors; licensee MDPI, Basel, Switzerland. This article is an open access article distributed under the terms and conditions of the Creative Commons Attribution license (http://creativecommons.org/licenses/by/3.0/). 